\title{
Pengaruh Naungan dan Variasi Sumber Pupuk Organik Cair terhadap Kadar Flavonoid Daun Bangun Bangun (Plectranthus amboinicus (Lour) Spreng)
}

\section{The Effect of Shading and Various Organic Liquid Fertilizer On The Levels Of Flavonoids In The Leaves Of Bangun Bangun (Plectranthus amboinicus (Lour) Spreng)}

Penulis

Afiliasi
Sofa Farida ${ }^{1} *$ Dian Susanti $^{1}$, Alifia Yuniarachma ${ }^{2}$

${ }^{1}$ Balai Besar Penelitian dan Pengembangan Tanaman Obat dan Obat Tradisional, Badan Litbang Kesehatan, Kementerian Kesehatan RI. Jl Raya Lawu No. 11 Tawangmangu, Karanganyar, Jawa Tengah, Indonesia 57792

${ }^{2}$ Fakultas Pertanian, Universitas Brawijaya, Malang

\section{Kata Kunci}

○ Flavonoid

O Naungan

$\rightarrow$ Plectranthus amboinicus

O Pupuk organik cair

\section{Keywords \\ O Flavonoids \\ $\rightarrow$ Liquid organic fertilizers \\ $\rightarrow$ Plectranthus amboinicus \\ $\rightarrow$ Shading}

Diterima 14 Maret 2019 Direvisi 2 September 2019 Disetujui 30 September 2019

*Penulis Koresponding Sofa Farida email: sofafarida9@gmail.com

\section{ABSTRAK}

Bangun-bangun [Plectranthus amboinicus (Lour.) Spreng] termasuk famili Lamiaceae yang memiliki aktivitas sebagai urolithiasis, fungitoxic, anti-bakteri, anti-malaria dan anti-radang. Lingkungan tumbuhan dan sistem budidaya bangun-bangun dapat mempengaruhi kadar senyawa metabolit sekunder terutama flavonoid. Penelitian ini bertujuan untuk mengetahui kandungan flavonoid total daun bangun-bangun dengan perlakuan naungan dan pupuk organik cair. Desain eksperimen menggunakan rancangan acak kelompok faktorial. Faktor pertama adalah variasi pupuk organik cair (0\% / tanpa pupuk organik cair, $100 \%$ daun kedelai, $100 \%$ batang pisang, jerami: sayuran 30\%: 70\%), sedangkan faktor kedua adalah empat tingkat persentase naungan (0\% / tanpa naungan, 40\%,60\%, dan $80 \%$ ). Oleh karena itu, terdapat 16 kombinasi perlakuan dengan masing-masing perlakuan diulang tiga kali, sehingga terdapat 48 unit percobaan. Penelitian dilakukan di Laboratorium Terpadu dan Kebun Produksi Karangpandan B2P2TO-OT selama bulan Juli-Oktober 2018. Perhitungan total flavonoid dilakukan dengan menggunakan metode spektrofotometri. Hasil penelitian menunjukkan bahwa tidak ada interaksi antara kedua faktor tersebut dan flavonoid total tidak berbeda nyata antar kelompok perlakuan. Namun, kelompok pupuk batang pisang dengan naungan $80 \%$ menghasilkan flavonoid total tertinggi.

\section{ABSTRACT}

Bangun-bangun [Plectranthus amboinicus (Lour.) Spreng] belongs to the Lamiaceae family which has urolithiasis, fungitoxic, anti-bacterial, anti-malaria and anti-inflammatory activity. The environment and cultivation systems can affect the levels of secondary metabolit compounds, especially flavonoids. This study aimed to determine the total flavonoid content of bangun-bangun's leaves with shade and liquid organic fertilizer treatment. The experimental design was a randomized factorial block design. The first factor was the variation of liquid organic fertilizer (0\% / without liquid organic fertilizer, 100\% soybean leaves, $100 \%$ banana stems, straw: vegetables 30\%: 70\%), while the second factor was four levels percentage of shading (0\% / without shade, 40\%, 60\%, and $80 \%)$. Therefore, there were 16 combinations of treatments, with each treatment was repeated three times, so that there were 48 experimental units. The study was conducted at B2P2TO-OT's Integrated Laboratory and Karangpandan Production Garden during July-October 2018. Calculation of total flavonoids was carried out using spectrophotometry method. The results showed that there were no interactions between the two factors and flavonoids total were not significantly different between treatment groups. However, the group with banana stem fertilizer and $80 \%$ shade treatment produced the highest total flavonoids. 


\section{PENDAHULUAN}

Bangun-bangun [Plectranthus amboinicus (Lour.) Spreng] merupakan tanaman daerah tropis yang daunnya memiliki aroma yang khas sehingga dikenal sebagai tanaman aromatik dan juga berfungsi sebagai tanaman obat. Bangun-bangun memiliki batang berbentuk bulat dan sedikit berambut, jarang berbunga (warnanya ungu putih), namun mudah sekali dibiakkan dengan stek dan cepat berakar di dalam tanah (Heyne 1987). Daun bangun-bangun secara turun temurun dimanfaatkan masyarakat Sumatra Utara sebagai menu sayuran serta bermanfaat untuk meningkatkan produksi ASI (Lactagogue) (Santosa \& Hertiani 2005; Damanik et al. 2006). Bangun-bangun telah diteliti memiliki aktivitas sebagai urolithiasis, fungitoxic, anti-bakteri, antimalaria dan anti-radang (Marpaung et al. 2014).

Bagian tanaman bangun-bangun yang dimanfaatkan adalah daun. Daun bangun-bangun memiliki kandungan magnesium, zat besi, zinc, kalsium, $\alpha$ tocopherol, $\beta$-karoten, polifenol, saponin, flavonoid serta minyak atsiri (Batubara et al. 2004; Santosa \& Hertianti, 2005). Flavonoid merupakan senyawa metabolit sekunder yang banyak ditemukan dalam semua tumbuhan hijau. Senyawa flavonoid adalah senyawa polifenol yang mempunyai 15 atom karbon membentuk dua cincin aromatik (Markham 1988). Senyawa golongan flavonoid memperlihatkan aktivitas seperti antifungi, diuretik, antihistamin, antihipertensi, insektisida, bakterisida, antivirus dan menghambat kerja enzim (Geissman 1962).

Lingkungan tumbuh dan sistem budidaya bangunbangun dapat mempengaruhi kadar senyawa metabolit sekunder, terutama flavonoid. Penelitian pengaruh pemupukan terhadap produksi fitokimia tanaman telah banyak dilakukan. Pupuk organik cair mampu menyediakan unsur hara lengkap yang dibutuhkan oleh tanaman untuk tumbuh karena lebih mudah diserap tanaman dibanding pupuk dalam bentuk padat. Pupuk organik cair juga mampu memperbaiki struktur tanah dan memperbaiki kehidupan mikroorganisme dalam tanah karena berperan positif terhadap tanaman yang akarnya mampu bersimbiosis dengan mikroorganisme pengikat nitrogen, salah satunya adalah tanaman leguminosae (Hadisuwito 2007; Hadisuwito 2012; Soenandar et al. 2010)

Pupuk organik cair diolah dari bahan baku berupa kotoran ternak, kompos, limbah alam, hormon tumbuhan, dan bahan-bahan alami lainnya yang diproses secara alamiah selama 2 bulan (Marpaung et al. 2014). POC yang berasal dari daun kacang kedelai mempunyai kemampuan untuk memfiksasi Nitrogen dari udara. Daun kacang kedelai juga mudah untuk diuraikan sehingga lebih cepat dalam proses pembuatan pupuk organik cair (Irwan 2006). POC dari batang pisang dipilih karena memiliki kandungan Nitrogen, Fosfor dan Kalium yang cukup tinggi sehingga mampu memberikan tambahan unsur pada tanaman bangun-bangun (Kusumawati 2015). Bahan ketiga berupa campuran jerami padi dan sayuran (bayam dan kangkung). Jerami padi banyak mengandung unsur Nitrogen dan Kalium dengan kandungan Kalium lebih mendominasi yaitu 5,35\%. Sayuran seperti bayam dan kangkung memiliki kandungan Kalium dan Fosfor yang cukup tinggi (Putri \& Abdul 2011).

Penelitian ini bertujuan untuk mengetahui pengaruh intensitas cahaya matahari dan perbedaan bahan POC serta interaksi kedua faktor tersebut terhadap produksi flavonoid daun bangun-bangun. Harapan dari penelitian ini adalah masyarakat memperoleh informasi teknik budidaya yang menunjang pembuatan SOP budidaya tanaman bangun-bangun yang mengandung senyawa bioaktif yang tinggi sebagai tanaman obat.

\section{METODE}

Penelitian dilakukan di Kebun Produksi Karangpandan B2P2TO-OT Tawangmangu, Kabupaten Karanganyar, Indonesia pada ketinggian 400 m dpl, selama bulan Juli hingga Oktober 2018. Analisis kandungan fitokimia dilakukan di Laboratorium Terpadu B2P2TO-OT. Percobaan disusun menggunakan Rancangan Acak Kelompok (RAK) Faktorial dengan dua faktor dan tiga ulangan. Faktor pertama adalah variasi POC dan faktor kedua adalah tingkat persentase naungan. Perlakuan terdiri dari 4 taraf yaitu PO (tanpa pupuk tambahan), P1 (daun kacang kedelai 100\%), P2 (batang pisang 100\%) dan P3 (jerami dan sayuran dengan rasio 30\%:70\%). Faktor naungan (N) juga terdiri dari 4 taraf yaitu 0, 40, 60, dan $80 \%$. Oleh karena itu, terdapat 16 kombinasi perlakuan (Tabel 1). 
Tabel 1. Kombinasi Perlakuan POC dan Naungan

\begin{tabular}{|c|c|c|c|c|}
\hline \multirow{2}{*}{ Variasi Perlakukan } & \multicolumn{4}{|c|}{ Naungan } \\
\hline & $0 \%$ & $40 \%$ & $60 \%$ & $80 \%$ \\
\hline Tanpa Pupuk & PONO & PON40 & PON60 & PON80 \\
\hline $\begin{array}{l}\text { Pupuk Daun Kedelai } \\
100 \%\end{array}$ & P1NO & P1N40 & P1N60 & P1N80 \\
\hline Pupuk Batang Pisang $100 \%$ & P2NO & $\mathrm{P} 2 \mathrm{~N} 40$ & $\mathrm{P} 2 \mathrm{~N} 60$ & $\mathrm{P} 2 \mathrm{~N} 80$ \\
\hline $\begin{array}{l}\text { Pupuk Jerami dan Sayuran } \\
\text { dengan Rasio 30\%:70\% }\end{array}$ & P3NO & P3N40 & P3N60 & P3N80 \\
\hline
\end{tabular}

Keterangan: $\mathrm{POC}=$ pupuk organik cair

Percobaan dilakukan dengan menggunakan stek batang bangun-bangun Stek batang yang digunakan pada proses budidaya yaitu bagian tengah dan pucuk. jumlah mata tunas yang disamakan dengan menyiisakan 2 mata tunas pada 1 batang utama, sehingga sebelumnya perlu dilakukan pruning terlebih dahulu sebelum melanjutkan proses pembibitan.Bibit bangun-bangun ditransplanting pada umur 3 minggu. Penanaman dilakukan pada media tanam yang telah dimasukkan dalam polybag (Aziz, 2013).

Panen dilakukan pada 6 minggu setelah tanam (MST) pada saat primordia bunga. Panen dilakukan dengan memotong bagian pucuk dan 4 pasang daun di bawahnya dengan menyisakan minimal 2 pasang daun bagian bawah. Selanjutnya sortasi dengan memisahkan daun, batang, calon bunga, bangun dan diambil hanya bagian daun.

\section{Berat basah dan kering daun total (g).}

Berat basah daun diperoleh dengan menimbang berat basah semua daun yang telah dipisahkan dari ranting hasil panen. Berat kering daun diperoleh dengan cara menimbang daun yang telah mengalami proses pengeringan dalam oven $50^{\circ} \mathrm{C}$ selama 4 hari.

\section{Kadar flavonoid total.}

Analisis flavonoid menggunakan metode Aluminium chloride colorimetric, Chang et al. (2002) dengan sedikit modifikasi.

\section{Analisis data.}

Analisis data yang digunakan yaitu analisis ragam uji $\mathrm{F}$ taraf $5 \%$ dan apabila beda nyata dilanjutkan dengan uji DMRT taraf $5 \%$

\section{HASIL \& PEMBAHASAN}

Residu tanaman kedelai berpotensi untuk digunakan sebagai pupuk organik karena memiliki kandungan unsur C Organik sebesar $37.2 \pm 0.63 \%$, Nitrogen (N) total $3.07 \pm 0.24 \quad(\%)$ nisbah $\mathrm{C} / \mathrm{N} \quad 12.3 \pm 0.74$, Hemiselulose $17.1 \pm 2.72 \%$, selulosa $26.8 \pm 2.13 \%$, dan lignin $2.89 \pm 0.74 \%$. Proses dekomposisi residu kedelai yang cukup cepat dipengaruhi oleh besar nisbah $\mathrm{C} / \mathrm{N}$, kandungan $\mathrm{N}$ dan komposisi sel dari residu tanaman kedelai khususnya lignin. Selain proses dekomposisi yang cepat, kedelai melepas unsur $\mathrm{N}$ ke tanah dalam jumlah yang signifikan (Gezahegn et al. 2016).

Batang pisang memiliki kandungan unsur $\mathrm{C}$-organik $7,32 \%$, Nitrogen total $0,21 \%$, Nisbah C/N 35, selulosa $63 \%$, hemiselulosa $20 \%$ dan lignin $5 \%$ (Kusmiadi $R$ et al. 2015; Sriharti \& Salim, 2008). Proses dekomposisi batang pisang lebih cepat daripada daun kedelai karena memiliki $\mathrm{C} / \mathrm{N}$ lebih tinggi. $\mathrm{N}$ total yang dilepaskan batang pisang lebih rendah daripada daun kedelai.

Berat basah (BB) daun bangun-bangun tertinggi diperoleh pada kombinasi perlakuan pupuk organik daun kedelai $100 \%$ dan naungan $40 \%$ (P1N40) sebesar $94,790 \mathrm{~g}$, sedangkan berat basah daun bangun-bangun terrendah pada kombinasi pupuk organik batang pisang $100 \%$ dan naungan 0\% (P2NO) sebesar 42,245g (Gambar 1). Berat kering daun bangun-bangun tertinggi diperoleh pada kombinasi perlakuan P1N40 yaitu 7,630 g, sedangkan P2N40 hanya memiliki berat kering terrendah sebesar 3,820 g (Gambar 2). Unsur hara N berperan dalam pertumbuhan vegetatif tanaman seperti pembentukan tunas, daun, peningkatan kandungan protein dan jumlah klorofil daun. Kekurangan $\mathrm{N}$ pada jaringan tanaman akan menyebabkan terjadinya klorosis daun, mudah gugur, pertumbuhan vegetatif terhambat dan terjadinya penurunan produksi tanaman (Harjanti et al. 2014; Hutahaean et al. 2013). 


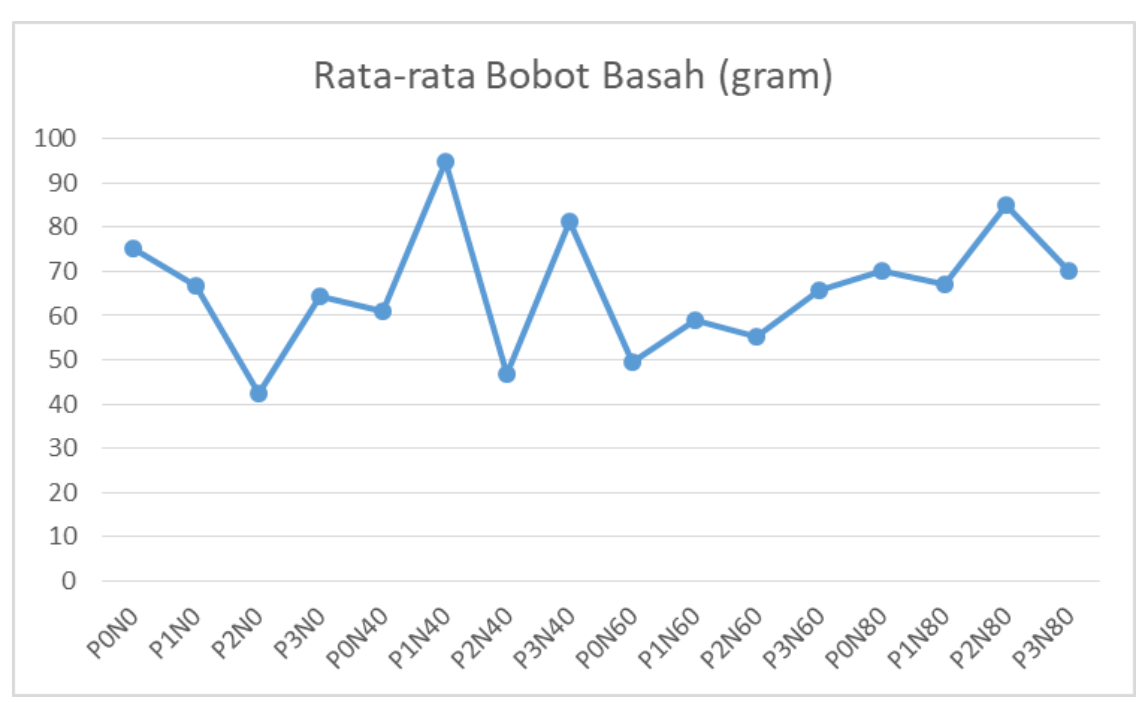

Gambar 1. Grafik Rata-Rata Berat Basah Daun Bangun-Bangun

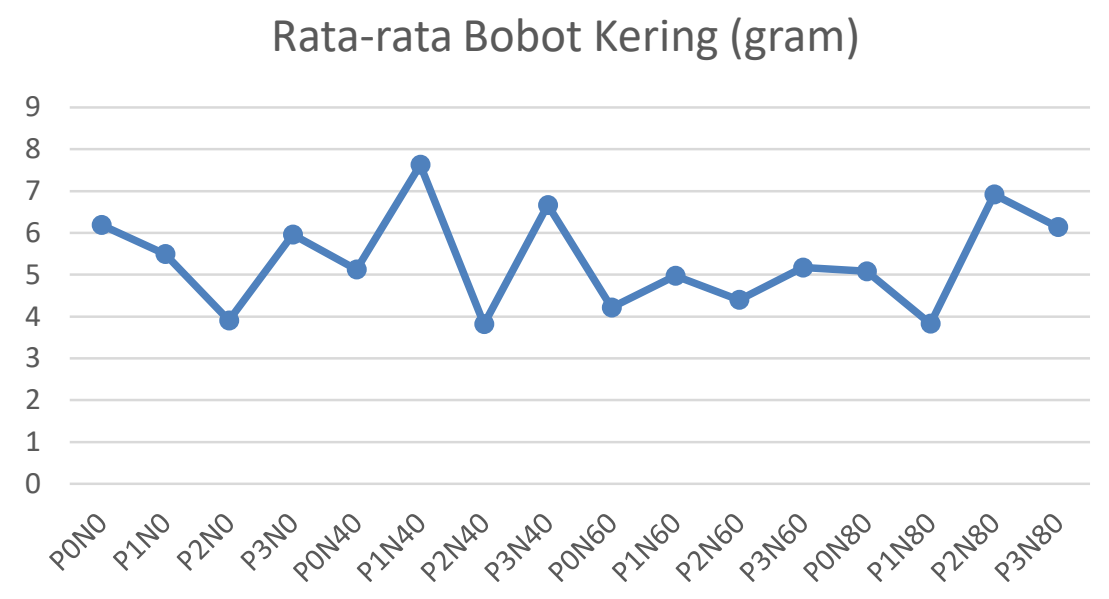

Gambar 2. Grafik Rata-Rata Bobot Kering Daun Bangun-Bangun

Selain unsur hara N, faktor lingkungan yang berpengaruh terhadap produksi daun tanaman adalah cahaya matahari. Pertumbuhan dan perkembangan tanaman memiliki ciri adanya pertambahan jumlah daun. Perlakuan naungan menurunkan jumlah daun bangun-bangun yang lebih sedikit dibandingkan dengan perlakuan tanpa naungan. Adanya naungan mempengaruhi pembentukan klorofil a dan klorofil b pada daun (Ekawati \& Aziz 2016). Adanya naungan menyebabkan tanaman tumbuh secara tidak optimal karena stress suhu terlalu panas. Tanaman yang tumbuh pada kondisi dengan jumlah naungan lebih banyak cenderung memiliki jumlah daun lebih banyak (Mansyur et al. 2019).

Berat basah dan berat kering daun dipengaruhi oleh efisiensi penyerapan dan pemanfaatan radiasi matahari yang sesuai. Paparan cahaya matahari yang optimal mampu meningkatkan bobot segar dan bobot kering tanaman (Buntoro et al. 2014). Kombinasi perlakuan P1N40 memiliki nilai biomassa tertinggi. Sehingga dapat disimpulkan daun melakukan penyerapan dan pemanfaatan sinar matahari optimal pada naungan $40 \%$ sehingga dapat menghasilkan nilai biomassa tertinggi.

Menurut Fitter dan Hay (1991) pada tanaman yang menggunakan cahaya sebagai sumber energi utamanya, intensitas cahaya mempengaruhi proses metabolisme melalui proses fotosintesis yang selanjutnya akan mempengaruhi pertumbuhan dan perkembangan tanaman. Sinar matahari merupakan sumber energi terbesar untuk aktivitas fotosintesis tumbuhan. Proses fotosintesis menghasilkan senyawa metabolit sekunder dan produk samping berupa ROS (reactive oxygen species). ROS bersifat toksik dan

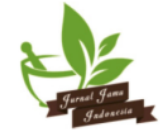




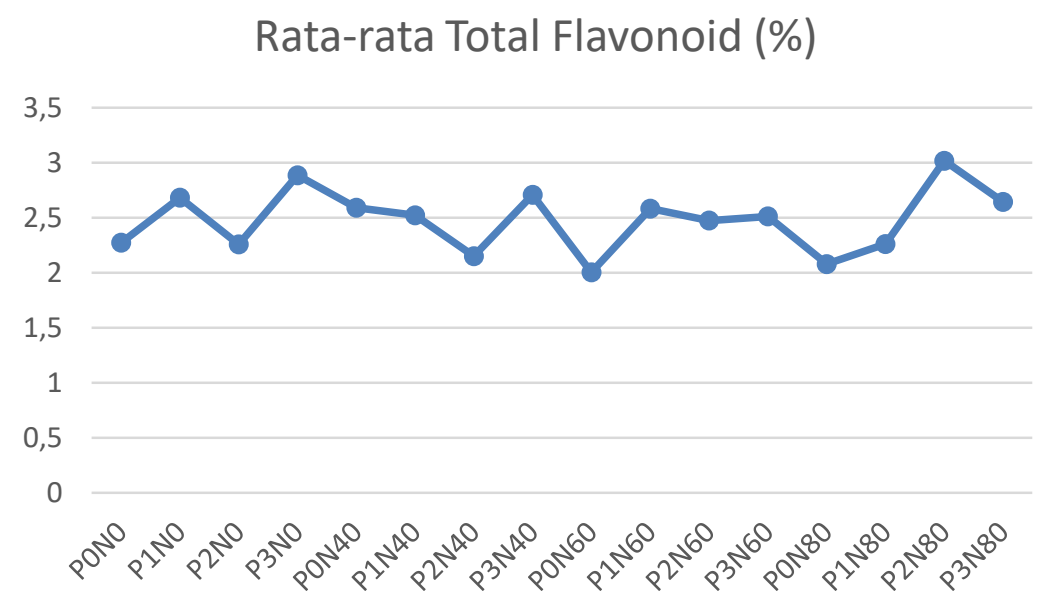

Gambar 3. Grafik Kadar Flavonoid Daun Bangun-Bangun

berpotensi merusak komponen fotosintesis. Senyawa fenolik memiliki aktivitas antioksidan yang dapat menjaga sel intraseluler mempertahankan kadar ROS pada level yang rendah. Oleh karena itu, sinar matahari merupakan salah satu faktor stres lingkungan primer, sehingga menjadi penyebab tingginya kadar fenolik (Shebis et al. 2013).

Pengujian flavonoid dilakukan menggunakan alat spektrofotometer UV-Vis. Penentuan kadar flavonoid didahului dengan pembuatan kurva standar yaitu kuersetin. Underwood (1990) mengemukakan bahwa kurva standar dibutuhkan sebagai pedoman untuk mengetahui hubungan antara konsentrasi larutan dengan nilai absorbansi sehingga konsentrasi sampel dapat diketahui. Rata-rata kadar flavonoid dari masingmasing kombinasi perlakuan dapat diamati pada Gambar 3.

Kombinasi perlakuan P2N80 memiliki rata-rata kadar flavonoid tertinggi yaitu sebesar 0,0182\%. Ratarata kadar flavonoid terendah didapatkan oleh kombinasi perlakuan P0N60 sebesar 2,005\%. Kombinasi perlakuan POC dan naungan tidak berpengaruh nyata terhadap total flavonoid, hal ini dibuktikan dengan perhitungan analisis ANOVA pada taraf $5 \%$.

Berdasarkan data berat basah, berat kering dan flavonoid dapat terlihat kombinasi perlakuan P1N40 (pupuk kedelai dengan naungan $40 \%$ ) merupakan teknik budidaya yang paling optimal untuk mendapatkan biomassa yang besar dengan total flavonoid yang cukup besar yaitu 2,52 \% diatas nilai kontrol (PONO) yang sebesar 2,27 \%.

\section{SIMPULAN}

Faktor kombinasi tidak memberikan pengaruh terhadap semua parameter pengamatan. Namun, kadar total flavonoid kombinasi POC batang pisang dengan naungan $80 \%$ (P2N80) memiliki nilai tertinggi sebesar 3,02 \%. Perlakuan P1N40 (pupuk kedelai dengan naungan $40 \%)$ merupakan teknik budidaya yang paling optimal untuk mendapatkan biomassa yang besar dengan total flavonoid yang cukup besar yaitu $2,52 \%$ diatas nilai kontrol.

\section{UCAPAN TERIMA KASIH}

Ucapan terimakasih dan penghargaan diberikan Kepala Balai Besar Tanaman Obat dan Obat Tradisional, PPI B2P2TOOT dan semua pihak yang telah memberikan kesempatan dan rnelancarkan kegiatan penelitian sampai dengan selesai.

\section{DAFTAR PUSTAKA}

Aziz SA. 2013. Plectranthus amboinicus. Bangunbangun, Torbangun. Sayur Fungsional Dibudidayakan Berdasarkan Budidaya yang Baik. Modul. Seafast Center IPB. Bogor. P:15-16

Batubara I, Mirtaningtyas V, Setyawan A, Haryati A, dan Nurmala I. 2004. Profil Unsur-unsur Penting ( $P, K$, $\mathrm{Ca}, \mathrm{Mg}$ dan $\mathrm{Fe}$ ) Flavonoid Daun Torbangun (Coleus amboinicus Lour) sebagai Gambaran Daun Torbangun dalam kesehatan Masyarakat. Bogor (ID): Pusat Studi Biofarmaka LPPM IPB.

Buntoro BH, Rogomulyo R, Trisnowati S. 2014. Pengaruh Takaran Pupuk Kandang dan Intensitas Cahaya Terhadap Pertumbuhan dan Hasil Temu Putih (Curcuma zedoaria L.). Vegetalika. 3(4): 29-39.

Chang CC, Yang MH, Wen HM, dan Chern JC. 2002. Estimation of Total Flavonoid Content in Propolis by Two Complementary Colorimetric Methodes. Journal of Food and Drug Analysis. 10(3):178-182 
Damanik R, Wahlqvist ML, dan Wattanapenpaiboon N. 2006. Lactagogue Effects of Torbangun, a Bataknese Traditional Cuisine. Asia Pacific Journal of Clinical Nutrition. 15(2): 267-274.

Ekawati R, and Aziz SA. 2016. Respon pertumbuhan dan fisiologis Plectranthus ambonicus (Lour) Spreng pada cekaman naungan. Agrovivor. 9(2): 82-89.

Fitter AH, dan Hay RKM. 1991. Fisiologi Lingkungan Tanaman. Yogyakarta (ID): Gadjah Mada University Press.

Geissman TA. 1962. The Chemistry of Flavonoid Compound. Pergamon Press. Oxford. P:51

Gezahegn AM, Ridzwan M, Halim A, and Yusoff MM. 2016. Decomposition and Nitrogen mineralization of Individual and Mixed Maize and Soybean Residue. MAYFEB Journal of Agricultural Science. 2:28-45.

Hadisuwito, Sukamto, 2007, Membuat Pupuk Kompos Cair, Cetakan ketiga, Jakarta (ID): Agromedia Pustaka,

Hadisuwito, S. 2012. Membuat Pupuk Organik Cair. Jakarta (ID): PT. Agro Media Pustaka

Harjanti RA, Tohari, and Utami SNH. 2014. Pengaruh takaran pupuk nitrogen dan silika terhadap pertumbuhan awal (Saccharum officinarum L.) pada inceptisol. Vegetalika. 3(2):35-44.

Heyne K. 1987. Tumbuhan Berguna Indonesia (Terjemahan). Jilid III. Jakarta (ID): Yayasan Sarana Wana Jaya, P:1556.

Hutahaean MU, Siagian B, and Mawarni L. 2013. Respons pertumbuhan bibit kakao terhadap pemberian kompos sampah kota dan pupuk $P$. Jurnal Online Agroekoteknologi. 1(4):1203-1216.

Irwan AW. 2006. Budidaya Tanaman Kedelai (Glycine Max (L.) Merril. Jatinangor (ID): Fakultas Pertanian Universitas Padjadjaran.

Kusmiadi R, Khodijah NS, and Royalaitani. 2015. Penambahan gedebog pisang pada kompos bulu ayam dengan berbagai jenis aktivator. Enviagro, Jurnal Pertanian Dan Lingkungan. 8(1):19-30.
Kusumawati A. 2015. Analisa Karakteristik Pupuk Kompos Berbahan Batang Pisang. Prosiding Seminar Nasional Universitas PGRI Yogyakarta. 19 Desember 2015, Yogyakarta, Indonesia. 323-329.

Mansyur AN, Triyono S, and Tusi A. 2019. Pengaruh naungan terhadap pertumbuhan sawi (Brassica juncea L) pada sistem hidroponik DFT (Deep Flow Technique). Jurnal Teknik Pertanian Lampung. 3(2): 103-110.

https://doi.org/10.1017/CB09781107415324.004

Markham KR. 1982. Cara Mengidentifikasi Flavonoid (Terjemahan). Bandung (ID): Penerbit ITB.

Marpaung A, Karo B, dan Tarigan R. 2014. Pemanfaatan Pupuk Organik Cair dan Teknik Penanaman dalam Peningkatan Pertumbuhan dan Hasil Kentang. Jurnal Hortikultura. 24(1): 49-55.

Putri NP, dan Kahar A. 2011. Pemanfaatan Sampah Sayuran Hijau dan Limbah Cair Urea sebagai Pupuk Cair. Prosiding Seminar Nasional Teknologi II Fakultas Teknik Universitas Mulawarman. 2011. Samarinda, Indonesia. 14-23.

Santosa CM. dan Hertiani T. 2005. Kandungan Senyawa Kimia dan Efek Ekstrak Air Daun Bangun Bangun (Coleus amboinicus L.) pada Aktivitas Fagositosis Netrofil Tikus Putih (Rattus norvegicus). Majalah Farmasi Indonesia. 16(3): 141-148.

Shebis Y, ILuz D, Tahan YK, Dubinsky Z, dan Yehoshua Y. 2013. Natural Antioxidant : Function and Sources. Food and Nutrition Sciences. 4: 634-64

Soenandar M, Nur AM, dan Raharjo A. 2010. Petunjuk Praktis Membuat Pestisida Organik. Jakarta (ID): PT. Agro Media Pustaka.

Sriharti, dan Salim T. 2008. Pemanfaatan limbah pisang untuk pembuatan kompos menggunakan komposter rotary drum. Prosiding Seminar Nasional Teknoin 2008 Bidang Teknik Kimia Dan Tekstil, (November), 978-979.

Underwood AL. 1990. Analisis Kimia Kuantitatif. Edisi 6. Jakarta (ID): Erlangga. 